\section{Innovation in Micro and Small Enterprises: Resources and Capabilities}

\author{
Inovação em Micro e Pequenas Empresas: Recursos e Capacidades
}

\section{ABSTRACT}

Objective: the article aims to identify the relevant resources for the composition of managerial and transactional capabilities in the context of micro and small enterprises (MSEs). Method: through a literature review, the resources associated with the innovation were identified: leadership, people management, information and knowledge, relationships with clients, suppliers, and society, and results. The resources were collected and measured using a structured questionnaire made available by the Local Agent for Innovation program, applied to 447 MSEs in the state of Pernambuco, between 2015 and 2017. Confirmatory factor analysis was used to verify how these resources contribute to the composition of capabilities. Results: the results demonstrate that the managerial capability is composed of the relationship with society and suppliers, leadership, the sharing of information and knowledge, and people management. Transactional capability is made up of the relationship with customers and the results obtained by the firm. Conclusions: although MSEs have restrictions on access to technologies, their organizational resources seem to contribute to the development of innovation capability and to obtain competitive advantage.

Keywords: innovation; dynamic capabilities; resource theory; micro and small enterprises.
1. Universidade Federal de Pernambuco, Centro de Ciências Sociais Aplicadas, Recife, PE, Brazil.

Cite as: Vasconcelos, R. B. B. de, Santos, J. F. dos, \& Andrade, J. A. de. (2021). Innovation in micro and small enterprises: Resources and capabilities. Revista de Administração Contemporânea, 25(2), e190106. https://doi.org/10.1590/1982-7849rac2021190106.en
Renata Braga B. de Vasconcelos ${ }^{10}$ Joséte Florencio dos Santos ${ }^{1}$ ( Jackeline Amantino de Andrade ${ }^{10}$

\section{RESUMO}

Objetivo: $\mathrm{o}$ artigo buscou identificar os recursos relevantes para composição das capacidades gerencial e comercial no contexto das micro e pequenas empresas (MPEs). Método: por meio de uma revisão da literatura, foram identificados os recursos associados à inovaçáo: liderança, gerenciamento de pessoas, informações e conhecimentos, relacionamento com clientes, fornecedores e sociedades, e resultados. Os recursos foram coletados e mensurados por meio de um questionário estruturado disponibilizado pelo programa Agente Local de Inovação, aplicado a 447 MPEs do estado de Pernambuco, entre 2015 e 2017. Utilizou-se análise fatorial confirmatória para verificar como esses recursos contribuem para composição das capacidades. Resultados: verificou-se que a capacidade gerencial é composta pelo relacionamento com a sociedade e fornecedores, a liderança, o compartilhamento de informações e conhecimentos, e o gerenciamento de pessoas. A capacidade comercial é composta pelo relacionamento com os clientes e os resultados obtidos pela firma. Conclusóes: apesar de as MPEs contarem com restriçóes ao acesso de tecnologias, seus recursos organizacionais parecem contribuir para o desenvolvimento da capacidade de inovaçấo e para obtenção de vantagem competitiva.

Palavras-chave: inovação; capacidades dinâmicas; teoria dos recursos; micro e pequenas empresas.

$\begin{array}{llllll}\text { \# of invited reviewers until the decision: } & \\ 1^{\text {st }} \text { round } \\ 2^{\text {nd }} \text { round } \\ 3^{\text {rd }} \text { round } \\ 4^{\text {th }} \text { round }\end{array}$




\section{INTRODUCTION}

Innovation can be understood as a driver of the economic performance of productive sectors, which leads to the economic development of nations through a process of creative destruction (Schumpeter, 1984, 1988). For this reason, technology and access to financial resources are essential to innovate (Schumpeter, 1984; Pavitt, 1984).

Nevertheless, Nelson and Winter (1982) see innovation as an essential and dynamic capability of firms to obtain competitiveness. The dynamic capability refers to the routines, capacities, skills, and experiences necessary to innovate. Thus, even if the technology is relevant, it is not enough to promote innovation, because innovation is the result of a complex process that depends on a set of resources and skills (Teece, 2007).

In this perspective, some authors have tried to understand how the innovation capability develops (Lawson \& Samson, 2001; Raghuvanshi, Ghosh, \& Agrawal, 2019; Zawislak, Alves, Tello-Gamarra, Barbieux, \& Reichert, 2012). Although there is no consensus on its operationalization (Iddris, 2019), studies show that technology is relevant, but organizational management plays an important role. Zawislak, Alves, Tello-Gamarra, Barbieux and Reichert (2012), for example, suggest that the innovation capability can be understood by technology and operations capabilities, but also by management and transaction ones.

However, these studies lack empirical evidence and emphasize large organizations, which have a superior management structure and better access to technologies and economies of scale. Instead, micro and small enterprises (MSEs) face financial and structural constraints, which can become obstacles to innovating (Kim, Park, \& Paik, 2018; Laforet \& Tann, 2006).

Saunilla (2019) suggests that studies that investigate innovation capability use to neglect the context of small enterprises. The restrictions and peculiarities that MSEs face reinforce the need to redefine the innovation capability construct and to identify the resources that are accessible and relevant to their context. Despite facing technological restrictions, Zawislak et al. (2012) and Zawislak, Fracasso and Tello-Gamarra (2018) emphasize the relevance of management and transaction capabilities for small firms. However, they do not identify relevant resources for MSEs that can contribute to these capabilities.

On the other hand, some studies based on the resource-based view (RBV) theory seek to analyze the determinants of innovation and identify resources that contribute to its development, including the context of small firms. Le and Lei (2019) and Martínez-Román and Romero (2017) emphasize that leadership and the sharing of ideas can promote innovation. Iddris (2019), in turn, points out the customer and supplier relationship. However, these studies seem dispersed and incomplete. They were limited to analyzing the relationship between innovation and an organizational management perspective. Furthermore, they do not demonstrate how resources can contribute to the innovation capability and the firms' abilities to manage their activities and commercialize their innovations.

Given the gaps verified in the literature, it is worth asking: how can MSEs become capable of being innovative? What resources can they obtain to develop their innovation capability? In this perspective, this article aims to identify the relevant resources for the composition of management and transaction capabilities in the MSEs context. The study presents a framework that allows investigating the phenomenon of innovation capability, demonstrating resources that can support MSEs in the management and commercialization of new ideas.

Thus, the article presents empirical and theoretical contributions. The managerial resources can become central to develop innovation in MSEs, given the technological constraints they face, but such resources are still seen as supplementary assets (Guan \& Ma, 2003; Kim et al., 2018). Therefore, the article seeks to overcome the constraints in the development of the innovations, enabling MSEs to identify managerial skills and resources to innovate, and to acquire, improve, and reconfigure them. It also turns possible to observe the difficulties and weaknesses in the use of these resources that can be remedied by support policies.

The research also focuses on the managerial perspective and presents the contribution of RBV (Penrose, 1959) to the study of dynamic capabilities (Dosi, Freeman, \& Nelson, 1988; Teece, Pisano, \& Shuen, 1997; Teece, 2007), providing a framework that facilitates understanding of how firms can develop their capabilities.

In the literature, some studies use RBV to analyze the relationship between managerial resources and innovation (Kamasak, 2015; Kim et al., 2018; Le \& Lei, 2019; Martínez-Román \& Romero, 2017; Vasconcelos \& Oliveira, 2018), however, do not include capabilities analysis. In contrast, this research seeks to observe how managerial resources can effectively contribute to the coordination of activities and the ability to commercialize new ideas, that is, to the management and transaction 
capabilities that constitute the innovation capability of the firms (Zawislak et al., 2012).

This paper is structured into four more sections. The following section presents the theoretical concepts about innovation, management and transaction capabilities, and the resources analyzed in this research. The third section covers the methodological procedures used, and the fourth reports the main results found in the study. The last section presents the conclusions, limitations, and considerations for future researches.

\section{THEORETICAL REFERENCE}

The dynamic capabilities of firms refer to the ability to configure and reconfigure internal and external competencies (Teece et al., 1997; Teece, 2007). Its relevance is getting new forms of competitive advantage, through a set of roles of strategic management that can be modified to the needs of environmental change (Teece et al., 1997).

The dynamic capabilities refer to the adaptive capacity of firms to achieve and sustain competitive advantages in the face of the constantly changing environments, the dynamism of globalization, and technological, systemic, and rapid changes (Teece et al., 1997; Teece, 2007).

More specifically, the innovation capability can be understood as the ability to continuously transform knowledge and ideas into new products, processes, and systems for the benefit of the firms and stakeholders (Lawson \& Samson, 2001). However, there is no consensus on its definition and on the skills needed to develop it.

Zawislak et al. (2012) for example, see the innovation capability as a technological learning process through managerial and commercial routines performed by the firm, to identify some capabilities that enable innovation.

The innovation capability is related to the "ability to absorb, to adapt, and to transform a given technology into specific management, operations, and transaction routines that can lead one firm to Schumpeterian profits" (Zawislak et al., 2012, p. 23). And it can be understood from a set of capabilities driven by technology and business, presented in Figure 1.

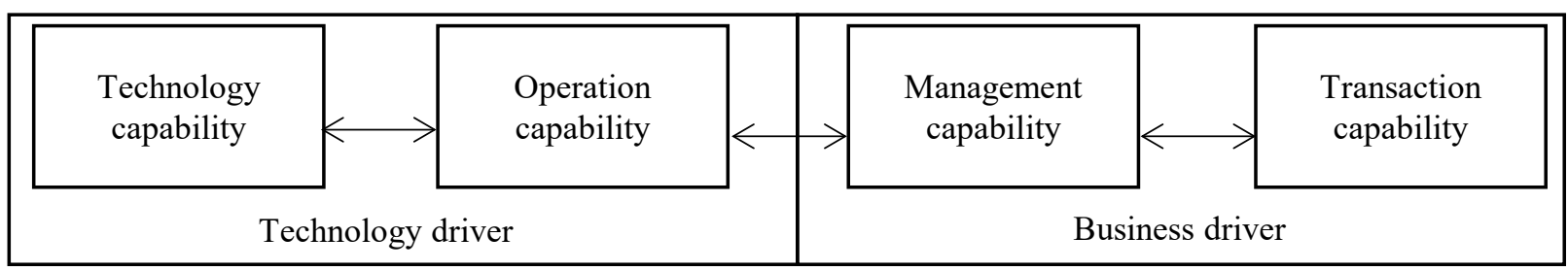

Figure 1. Innovation capability.

Source: adapted from Zawislak, P., Alves, C., Tello-Gamarra, J., Barbieux, D., \& Reichert, F. (2012). Innovation capability: from technology development to transaction capability. Journal of Technology Management \& Innovation, 7(2), 14-27. https://doi.org/10.4067/S0718-27242012000200002

Technology and operations capabilities constitute the technology driver - they refer, respectively, to the ability to obtain and apply new knowledge and market solutions, and to the ability to exploit operations with quality, flexibility, low cost, delivery times, etc. (Alves, Barbieux, Reichert, Tello-Gamarra, \& Zawislak, 2017). The management and transaction capabilities compose the business driver. The first one is related to the coordination of resources and activities (Alves et al., 2017), and the second one refers to the search for information in the market to reduce transaction costs (Coase, 1937; Williamson, 1985).

The framework proposed by Zawislak et al. (2012) suggests that firms have some knowledge advantage, which can be translated into technology, new products, and processes and be traded by the firms. For that, firms must use routines and procedures to operate this technology.

Thus, "the potential technological solution to be translated into an operational arrangement must be efficiently managed to guarantee the delivery of the expected outcome" (Zawislak et al., 2012, p. 20). Therefore, managerial skills are relevant to transform innovation into a competitive advantage. Even if the technology is operationalized, it is necessary to connect the firms to the market, through commercial activities of customer service, marketing, logistics that drive technological changes.

Raghuvanshi, Ghosh and Agrawal (2019) present a different framework from Zawislak et al. (2012), but they also emphasize the relevance of organizational management, which constitute the pillars of innovation 
capability. Guan and Ma (2003) also indicate that technology capabilities are not sufficient to support superior performance. They highlight investments in research and development (R\&D) and manufacturing for business competitiveness, but also emphasize organizational and strategic skills as supplementary assets, which enable sustainable performance.

Likewise, Kim et al. (2018) indicate that the ability to transform investments in $\mathrm{R} \& \mathrm{D}$ into products is pertinent to innovate, but also suggest that the ability to commercialize and analyze competitors influences the relationship between innovation and the firm's performance. As can be seen, the capabilities related to organizational management can be relevant to innovations development, and become even more necessary in the context of MSEs, given the difficulties they face in accessing technology (Laforet \& Tann, 2006).

Despite their constraints, MSEs represent a significant part of the economy of several countries (Lee \& Newton, 2000). In Brazil, small businesses represent $98.5 \%$ of the total of private companies, and they are responsible for about $30 \%$ of the gross domestic product and $51 \%$ of employment (Serviço Brasileiro de Apoio às Micro e Pequenas Empresas [Sebrae], 2020).

According to Law no. 155 (Lei n. $\left.{ }^{\circ} 155,2016\right)$, MSEs are firms that earn less than $\mathrm{R} \$ 4,800,000.00$ (four million and eight hundred thousand reais) of gross annual revenue. However, $88 \%$ refer to micro-enterprises, whose annual revenue is less than $\mathrm{R} \$ 360,000.00$ (three hundred and sixty thousand reais). Most of them are family businesses and employ less than ten employees, and they concentrate their business activity on the commerce and service (Sebrae, 2020).

Nevertheless, Laforet and Tann (2006) point out that MSEs face constraints in accessing technologies, capital, and obtaining economies of scale, which can difficult innovation development. Despite structural and technological restrictions, Vasconcelos and Oliveira (2018) demonstrate that MSEs can create new products and services, and innovate in communication channels and organizational arrangements, using business-driven capabilities.

The comprehension of these capabilities, however, involves analyzing the resources that drive their development. Penrose (1959) suggests that firms are like a bundle of heterogeneous resources, and the firms can combine them. The resource-based view can help to understand how strategic and organizational processes can support the firms to respond to changes by modifying its resources and creating innovations (Eisenhardt \& Martin, 2000). After all, firms can reconfigure their innovation capabilities and promote new arrangements that favor competitiveness (Tometich, Fracasso, Zen, \& Engelman, 2019).

\section{Zawislak et al. (2018), for example, identify} resources associated with business-driven capabilities. According to the authors, management capability is related to strategic planning, human resources, and norms and procedures. Transaction capability involves customer relationship, bargaining power, and contract management with customers and suppliers. However, as they point out, the research has some limitations, and they suggest the development of a quantitative study through a sectoral analysis.

On the other hand, Bayarçelik, Tasel and Apak (2014), Karpak and Topcu (2010), Le and Lei (2019), Martínez-Román and Romero (2017) and Vasconcelos and Oliveira (2018) present factors that can contribute to innovation capability and its performance in small firms. They emphasize resources as leadership, relationship with customers and society, the use of networks, etc. But the studies establish a direct relation between resources and innovation or its capability.

Diversely, this study suggests that these resources can contribute specifically to the development of management and transaction capabilities that promote innovation, which requires an analysis of these resources and relationships.

\section{Resources related to innovation capability}

In the literature, there is no accepted structure for investigating the innovation capability because there is no consensus in its definition and operationalization (Iddris, 2019). The studies address different resources associated with the ability to innovate (Bayarçelik, Taşel, \& Apak, 2014; Iddris, 2019; Kamasak, 2015; Kim et al., 2018; Le \& Lei, 2019; Rogers, 2004; Silva, Mainardes, Raposo, \& Sousa, 2012; Vasconcelos \& Oliveira, 2018).

In general, these studies identify some determinants for innovation capability and its performance, and they use different contexts and approaches. By reviewing these works, it is possible to identify resources that can contribute to the business-driven capabilities, as presented in Table 1. 
Table 1. Literature review.

\begin{tabular}{|c|c|c|c|}
\hline Authors & Method & Analysis level & Main results \\
\hline Rogers (2004) & Probit regression & Australian firms & $\begin{array}{l}\text { There is a positive association between the use of networks and innovation in small } \\
\text { manufacturing firms. }\end{array}$ \\
\hline $\begin{array}{l}\text { Bos-Brouwers } \\
(2009)\end{array}$ & Case study & $\begin{array}{l}\text { Small and medium-sized } \\
\text { enterprises (SMEs) in the } \\
\text { Netherlands SMEs }\end{array}$ & $\begin{array}{l}\text { Dynamic and entrepreneurial leadership favors innovation. The focus on } \\
\text { sustainability and information sharing promotes activities with innovative potential. }\end{array}$ \\
\hline $\begin{array}{l}\text { Karpak and Topcu } \\
(2010)\end{array}$ & ANP & Experts in SMEs & $\begin{array}{l}\text { The entrepreneur's personality, knowledge, and skills, and market regulation and } \\
\text { policy contribute to SME's success. }\end{array}$ \\
\hline Söllner (2010) & Probit regression & German enterprises & There is a positive association between the diversity of human capital and innovation. \\
\hline Laforet (2011) & $\begin{array}{l}\text { Grounded theory, } \\
\text { interviews }\end{array}$ & SME managers & $\begin{array}{l}\text { The study identifies some drivers of innovation, such as the market environment, } \\
\text { relationships with customers and competitors, managerial skills, financial results, } \\
\text { and company growth. }\end{array}$ \\
\hline $\begin{array}{l}\text { Silva, Mainardes, } \\
\text { Raposo and Sousa } \\
\text { (2012) }\end{array}$ & Logit regression & $\begin{array}{l}\text { Services companies in } \\
\text { Portugal }\end{array}$ & $\begin{array}{l}\mathrm{R} \& \mathrm{D} \text { investments, information sharing, and marketing activities contribute to } \\
\text { innovation. }\end{array}$ \\
\hline $\begin{array}{l}\text { Bayarçelik et al. } \\
(2014)\end{array}$ & AHP & Turkish SMEs & $\begin{array}{l}\text { The skills of managers, financial aspects, and market orientation are relevant to the } \\
\text { innovation process. }\end{array}$ \\
\hline $\begin{array}{l}\text { El Elj and Abassi } \\
(2014)\end{array}$ & Regression & $\begin{array}{l}\text { Mediterranean industrial } \\
\text { firms }\end{array}$ & $\begin{array}{l}\text { Absorption capacity depends on the learning and knowledge generated by the firm } \\
\text { that contributes to the willingness to innovate. }\end{array}$ \\
\hline $\begin{array}{l}\text { Genis-Gruber and } \\
\text { Öğüt }(2014)\end{array}$ & Logit regression & $\begin{array}{l}\text { Chemical, plastic, steel, } \\
\text { and furniture industry } \\
\text { from the European Union }\end{array}$ & Customers' and suppliers' characteristics affect the motivation for innovation. \\
\hline $\begin{array}{l}\text { Farace and Mazzotta } \\
(2015)\end{array}$ & Probit regression & $\begin{array}{l}\text { Manufacturing SMEs } \\
\text { from the south of France }\end{array}$ & $\begin{array}{l}\text { The human capital, the entrepreneurs, and knowledge networks contribute to the } \\
\text { absorption capacity that facilitates innovation. }\end{array}$ \\
\hline Kamasak (2015) & $\begin{array}{l}\text { Factor analysis and } \\
\text { linear regression }\end{array}$ & 194 enterprises & $\begin{array}{l}\text { The relationship with customers and suppliers and the culture of innovation are } \\
\text { related to innovation performance. }\end{array}$ \\
\hline $\begin{array}{l}\text { Martínez-Román } \\
\text { and Romero (2017) }\end{array}$ & Linear regression & Spanish SMEs & $\begin{array}{l}\text { The entrepreneur's motivation, business planning, and knowledge networks are } \\
\text { significant for developing core innovations. }\end{array}$ \\
\hline $\begin{array}{l}\text { Kim, Park and Paik } \\
(2018)\end{array}$ & $\begin{array}{l}\text { Exploratory } \\
\text { factorial analysis }\end{array}$ & $\begin{array}{l}\text { SMEs listed on the North } \\
\text { Korea stock exchange }\end{array}$ & $\begin{array}{l}\text { The management leadership and the knowledge network facilitate innovation } \\
\text { capability and contribute to the performance of firms. }\end{array}$ \\
\hline $\begin{array}{l}\text { Vasconcelos and } \\
\text { Oliveira (2018) }\end{array}$ & $\begin{array}{l}\text { Linear regression } \\
\text { and data } \\
\text { envelopment } \\
\text { analysis }\end{array}$ & Brazilian MSEs & $\begin{array}{l}\text { Leadership, information and knowledge, relationship with customers and society } \\
\text { drive the innovation capability and its efficiency. }\end{array}$ \\
\hline $\begin{array}{l}\text { Vasconcelos, Vieira } \\
\text { and Silveira (2020) }\end{array}$ & $\begin{array}{l}\text { Panel data } \\
\text { regression }\end{array}$ & Food service MSEs & $\begin{array}{l}\text { The internal processes and the results achieved by the firms are the main } \\
\text { determinants of innovation. }\end{array}$ \\
\hline Iddris (2019) & Study case & $\begin{array}{l}\text { Low-tech manufacturing } \\
\text { SMEs }\end{array}$ & $\begin{array}{l}\text { The collaboration with institutional agents, customers, and suppliers influences the } \\
\text { innovation capability. }\end{array}$ \\
\hline Le and Lei (2019) & $\begin{array}{l}\text { Confirmatory } \\
\text { factorial analysis }\end{array}$ & $\begin{array}{l}\text { Chinese manufacturing } \\
\text { and service companies }\end{array}$ & $\begin{array}{l}\text { Transformative leadership and information sharing impact contribute to the } \\
\text { promotion of innovation. }\end{array}$ \\
\hline
\end{tabular}

The literature review indicates that the resources related to the development of innovation are still dispersed and incomplete. Each study analyzes an innovation perspective, but the overview makes it possible to identify resources that may be associated with management and transaction capability.

The review focused on the resource-based view theory identified seven constructs associated with managerial resources and enabled the development of hypotheses related to capabilities. The resources are: (a) leadership; (b) information and knowledge; (c) people management; (d) business-society relationship; (e) supplier relationship; (f) customer relationship; (g) results.

\section{Leadership}

The leaders have a central role in promoting organizational changes and defining projects (Teece, 2007). They can encourage and share information with their stakeholders to develop innovations (Vasconcelos, Vieira, \& Silveira, 2020) and engage people to implement organizational changes (Popadiuk, Luz, \& Kretschmer, 2018). For Iddris (2019), the perception of entrepreneurs 
through the interactive learning that they maintain with stakeholders can help to develop innovations.

Empirical studies suggest that the experiences and knowledge of leaders and their management style promote innovation in large organizations (Le \& Lei, 2019) and small ones (Bayarçelik et al., 2014; Karpak \& Topcu, 2010; Kim et al., 2018; Martínez-Román \& Romero, 2017). For Bayarçelik et al. (2014), the leader's management style favors the obtaining of external information and encourages experimentation and entrepreneurship.

From this context, it is possible to presume that the leader management strategies, his search for knowledge, and information sharing can contribute to the management of resources and activities, that is, to the management capability. Then, the following hypothesis is proposed:

$\mathrm{H}_{1}$. Management capability is positively related to leadership.

\section{Information and knowledge}

The networks and knowledge sharing between firms facilitate the adoption of effective business strategies that improve innovation performance (Kamasak, 2015; Laforet, 2011; Le \& Lei, 2019). The use and sharing of information and knowledge can lead to radical and sustainable innovations (Bos-Brouwers, 2009), although their effects may vary according to the size and company industry (Rogers, 2004).

Some empirical studies in SMEs corroborate these findings. Farace and Mazzotta (2015), Kim et al. (2018) and Martínez-Román and Romero (2017) indicate that networks contribute positively to innovation capability, and the access to knowledge can improve organizational processes. These studies suggest that sharing information with stakeholders can develop processes, activities, and routines. Thus, the second hypothesis of this research assumes that:

$\mathrm{H}_{2}$. The management capability is positively related to the information and knowledge shared by the firm.

\section{People management}

According to Farace and Mazzotta (2015), Laforet (2011) and Söllner (2010), innovation capability also depends on the employees' abilities. Thus, the construction of an innovative environment must begin with the recruitment process and pass through training and qualifications that encourage team autonomy.

Söllner (2010) emphasizes that diversity in human resources (ages, genders, education) encourages ideas generation. Contrarily, the rigidity in the definition and execution of tasks can reduce this potential (Vasconcelos \& Oliveira, 2018).

The studies suggest that people management process tends to support the coordination of activities and resources, contribute to management capability, and stimulate the development of innovations.

$\mathrm{H}_{3}$. Management capability is positively related to people management.

\section{Business-society relationship}

According to Karpak and Topcu (2010), policies and regulations create conditions for the prosperity and development of innovations. Nidumolu, Prahalad and Rangaswami (2009) and Vasconcelos and Oliveira (2018) clarify that policies and rules, whether economic, social, or environmental, can encourage the development of creative solutions and proactivity in meeting government regulations.

Thus, meeting legal, social, and environmental requirements can allow the firm to understand its environment and reevaluate its activities and processes, that is, to improve the management capability.

$\mathrm{H}_{4}$. Management capability is positively related to business-society relationship.

\section{Supplier relationship}

Kamasak (2015) suggests that the partnership relationship with suppliers is a critical factor in the development of innovations. According to the author, the suppliers can provide new ideas to the firm and support a competitive advantage.

Iddris (2019), highlights that suppliers promote the development of innovations in MSEs, as suppliers of machines, equipment, and feedstock provide training to the firm, which can improve the ability to innovate. Nevertheless, Zawislak et al. (2018), argue that the innovation capability depends on the bargaining power and contract management that firms exert on suppliers, that is, the firm's ability to influence the terms and conditions of the contract to obtain commercial advantages and reduce transaction costs.

In general, the studies indicate that the supplier relationship can facilitate commercial activities and reduce transaction costs that are associated with transaction capability.

$\mathrm{H}_{5}$. Transaction capability is positively related to supplier relationship. 


\section{Customer relationship}

Collaboration and integration with customers can promote innovation (Genis-Gruber \& Öğüt, 2014; Kamasak, 2015; Laforet, 2011). For Kamasak (2015), consumer knowledge is an innovation driver, and he suggests the customer's engagement to achieve success in innovations.

According to Bayarçelik et al. (2014), the close relationship of small firms to their customers and the market is a central resource in the innovation process, because the consumer demands and the market conditions can imply the development of new products. It is possible to propose an association of customer relationship to transaction capability, since the efforts to understand the customer and market needs are relevant to the development of innovations and can favor their commercialization.

$\mathrm{H}_{6}$. Transaction capability is positively related to customer relationship.

\section{Results}

Bayarçelik et al. (2014), Laforet (2011) and Vasconcelos et al. (2020) perceive a positive relationship between the firm's performance and innovations. The financial results are necessary to develop and operate innovation (Bayarçelik et al., 2014), and the expected profit and growth act as drivers for this activity (Laforet, 2011). Such studies are consistent with Schumpeter (1988), who understands that credit plays a crucial role for innovation.

Vasconcelos et al. (2020) point out the relevance of non-financial results, which also represent the return for the selling effort. Thus, the transaction capability may have a positive relationship with the results achieved by the firm, since they enable the reduction of transaction costs.

$\mathrm{H}_{7}$. Transaction capability is positively related to the results obtained by the firm.

As can be seen, the resources presented in this study can influence the development of businessdriven capabilities. Therefore, it is necessary to analyze the relationships mentioned. Despite the theoretical classification, the capabilities are closely related, and jointly favor the development of innovation (Zawislak et al., 2012). Therefore, there may be a relationship between the capabilities, as stated above.

$\mathrm{H}_{8}$. Management and transaction capabilities are positively related to each other.

\section{METHODOLOGICAL PROCEDURES}

This study develops exploratory research to obtain a better understanding of the phenomenon and uses a quantitative approach with transversal data. The population consisted of MSEs participating in the Local Agent for Innovation (ALI) program, located in the state of Pernambuco, between 2015 and 2017. We considered as MSEs those organizations covered by Law no. 155 (Lei n. ${ }^{\circ}$ 155, 2016).

A total of 2,838 MSEs participate in the ALI program, and 447 firms were randomly selected, providing an error of $4.25 \%$ and a confidence level of $95 \%$. We prior the most representative industries for the selection: gastronomy, bakery, furniture, clothing manufacturing, fashion retailing, building materials, and hotels and tourism. The sample is composed of firms that belong to low-technological intensity industries.

The data were obtained from a secondary source: the database of the ALI program, provided by Sebrae. The ALI program applies a survey to entrepreneurs and directors in MSEs to diagnose organizational management. The instrument consists of 37 questions that analyze the management. However, in this study, we considered the questions that reflect the resources mentioned in the literature, totaling 32 questions.

Studies conducted by Vasconcelos and Oliveira (2018) and Vasconcelos et al. (2020) partially used the survey to analyze organizational resources, which validate the instrument. The data collected refer to the initial business diagnosis, performed before the participation of firms in the program. Thus, the interventions developed by the ALI did not affect the results obtained. Table 2 presents the aspects analyzed and the studies related to the formation of the constructs.

Each aspect analyzed refers to a question in the survey, measured using a scale from 0 to 3 points. The 0 (zero) indicates the firm does not use the resource evaluated, and the 3 (three) indicates its consistent and formalized adoption. The resources were measured using an index, calculated by the total points obtained in the questions of the construct divided by the maximum score of the construct. No missing values were found due to the data collection strategy, and the analysis of standardized residues did not indicate the presence of outliers. 
Table 2. Internal resources related to organizational management.

\begin{tabular}{|c|c|c|}
\hline Resources & Aspects analyzed & Related studies \\
\hline $\begin{array}{l}\text { Leadership } \\
\text { (Leadership) }\end{array}$ & $\begin{array}{l}\text { Mission statement } \\
\text { Encouraging ethical behavior } \\
\text { Performance analysis by leaders } \\
\text { Information sharing by leaders } \\
\text { Search for innovation opportunities }\end{array}$ & $\begin{array}{l}\text { Bayarçelik et al. (2014), Bos-Brouwers (2009), Kim et al. (2018), } \\
\text { Laforet (2011), Le and Lei (2019), Martínez-Román and Romero } \\
\text { (2017), Vasconcelos and Oliveira (2018). }\end{array}$ \\
\hline $\begin{array}{l}\text { Information and } \\
\text { knowledge } \\
\text { (Information) }\end{array}$ & $\begin{array}{l}\text { Definition and availability of information for decision- } \\
\text { making } \\
\text { Encouraging knowledge sharing } \\
\text { Use of information to promote improvements } \\
\text { Use and obtaining of comparative information }\end{array}$ & $\begin{array}{l}\text { Bos-Brouwers (2009), El Elj and Abassi (2014), Kamasak (2015), } \\
\text { Kim et al. (2018), Laforet (2011), Le and Lei (2019), Martínez- } \\
\text { Román and Romero (2017), Rogers (2004), Silva et al. (2012), } \\
\text { Vasconcelos and Oliveira (2018). }\end{array}$ \\
\hline $\begin{array}{l}\text { People management } \\
\text { (People) }\end{array}$ & $\begin{array}{l}\text { Definition of roles and responsibility } \\
\text { Recruitment and selection process } \\
\text { Employee training and development } \\
\text { Identification of workplace hazards and risks } \\
\text { Promotion of well-being and satisfaction }\end{array}$ & Farace and Mazzotta (2015), Söllner (2010). \\
\hline $\begin{array}{l}\text { Business-society } \\
\text { relationship } \\
\text { (Society) }\end{array}$ & $\begin{array}{l}\text { Knowledge of legal requirements } \\
\text { Mitigation of environmental impacts } \\
\text { Development of social projects }\end{array}$ & $\begin{array}{l}\text { Bos-Brouwers (2009), Karpak and Topcu (2010), Laforet and } \\
\text { Tann (2006), Vasconcelos and Oliveira (2018). }\end{array}$ \\
\hline $\begin{array}{l}\text { Supplier } \\
\text { relationship } \\
\text { (Supplier) }\end{array}$ & $\begin{array}{l}\text { Suppliers selection and evaluation } \\
\text { Business process standardization } \\
\text { Process control }\end{array}$ & $\begin{array}{l}\text { Genis-Gruber and Öğüt (2014), Iddris (2019), Kamasak (2015), } \\
\text { Vasconcelos et al. (2020). }\end{array}$ \\
\hline $\begin{array}{l}\text { Customer } \\
\text { relationship } \\
\text { (Customer) }\end{array}$ & $\begin{array}{l}\text { Identification of customer needs } \\
\text { Promotion of products and services } \\
\text { Complaints handling procedure } \\
\text { Customer satisfaction assessment } \\
\text { Use of customer information for decision-making }\end{array}$ & $\begin{array}{l}\text { Bayarçelik et al. (2014), Genis-Gruber and Öğüt (2014), Iddris } \\
\text { (2019), Kamasak (2015), Laforet (2011), Silva et al. (2012), } \\
\text { Vasconcelos and Oliveira (2018). }\end{array}$ \\
\hline $\begin{array}{l}\text { Results } \\
\text { (Results) }\end{array}$ & $\begin{array}{l}\text { Customer satisfaction and complaints results } \\
\text { Employee training results } \\
\text { Labor productivity results } \\
\text { Profit margin results }\end{array}$ & Bayarçelik et al. (2014), Laforet (2011), Vasconcelos et al. (2020). \\
\hline
\end{tabular}

Note. The table presents the constructs related to the organizational resources. The aspects analyzed refer to the questions formulated to evaluate the construct, using a scale of 0 to 3 points. The related studies indicate the literature used to support the construct formulation.

\section{Confirmatory factor analysis}

Confirmatory factor analysis (CFA) method was performed to achieve the objective proposed in the article. The CFA allows testing the relationship between the latent and observed variables and composes the constructs. The observed variables refer to the resources identified in the literature, and the latent variables refer to the management and transaction capabilities.

The CFA groups variables that share characteristics of variance and covariance around factors with a minimal overall loss of information (Brown, 2015). In this study, its contribution is to validate the resources that contribute to the constructs related to capabilities, as established in the research hypotheses.

Figure 2 presents the proposed model based on theoretical considerations. The arrows suggest the direction of the expected relationships, formulated according to the hypotheses. The model proposes that management and transaction capabilities (ellipses) are composed of the set of resources (rectangles).

The Kolmogorov-Smirnov test did not verify the normality of the variables, and thence the CFA used the maximum likelihood estimator. The adjustment indices and the residual covariance matrix evaluated the model fit and suggested changes to the original model.

The $\chi 2$ test evaluated the capacity of the estimated model to reproduce the covariance matrix of the sample. The root mean square error of approximation (RMSEA) estimated whether the models are capable of reproducing the population covariance, and the standardized root mean square residual (SRMR) verified differences between the predicted and observed covariances. 


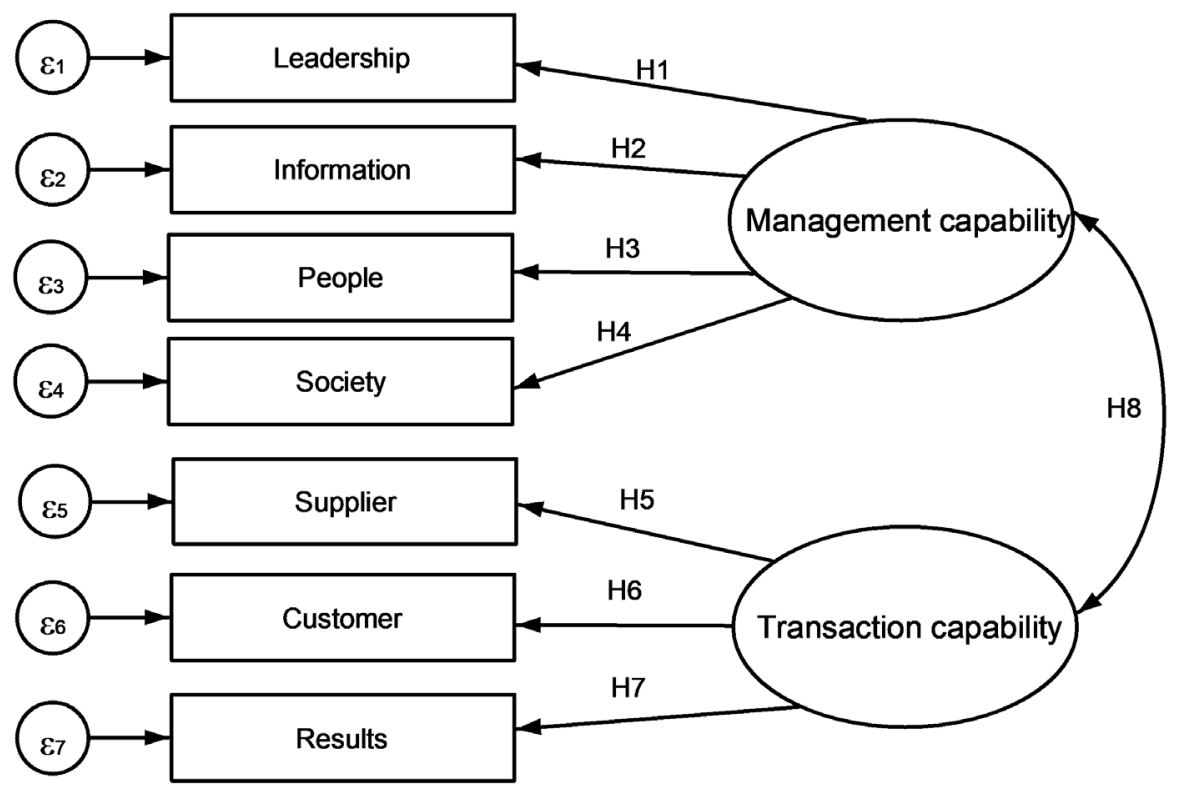

Figure 2. Confirmatory factor analysis model.

Ellipses represent latent variables, rectangles represent observed variables, and arrows represent the direction of the relationship. $\varepsilon_{1}$ to $\varepsilon_{7}$ indicate the measurement error of the observable variables. $H_{1}$ to $H_{8}$ indicate the model's hypotheses.

The robust comparative fit index (CFI) and robust Tucker-Lewis index (TLI) verified the fit of the model by comparing it with a standard model. In addition, the factor loading analysis served to adjust the model. The nonsignificant relationship and the factor loading smaller than 0.40 were excluded since there is no empirical evidence for its maintenance, which may affect the model reliability (Brown, 2015). The CFA estimates and the adjustment indices were performed using the lavaan package of the $\mathrm{R}^{\oplus}$ software.

Cronbach's alpha and McDonald's omega analyzed reliability. The average variance extracted (AVE), which represents the average variance between observed and latent variables, measured the convergent validity of the model. In addition, the Heterotrait-Monotrait ratio of correlations (HTMT) verified the discriminant validity of the constructs. These tests were performed using the semTools package of the $\mathrm{R}^{\bullet}$ software. Finally, an in-sample robustness test was performed, through the random selection of five samples composed of 300 firms.

\section{RESULTS}

Initially, this section presents information about the study sample and descriptive statistics of the observed variables. Posteriorly, the CFA results are presented.

Table 3 shows the sample composition. There are a high concentration of enterprises in the bakery industry (71 MSEs) and a low concentration on the furniture industry (53 MSEs). Nevertheless, there is a balanced sample of the industries sectors. The majority of firms $(66.55 \%)$ have been in existence for between 5 and 20 years, revealing that they are mature companies, which overcame initial barriers. Most of the firms have few employees - $66 \%$ of the sample have up to 10 employees, and only $8.05 \%$ have more than 30, consistent with the profile of Brazilian SMEs (Serviço Brasileiro de Apoio às Micro e Pequenas Empresas [Sebrae], 2018). 73.60\% are located in the metropolitan region of Recife, while $26.4 \%$ are in other locations (north and south coasts, agreste, sertão, and zona da mata).

Table 4 presents the mean of each variable by the industries analyzed. The Kruskal-Wallis test verified differences in the resources for each industry sector, indicating that the firms use different combinations of the resources to answer the environment demands, as suggested by Penrose (1959). 
Table 3. Sample composition.

\begin{tabular}{|c|c|c|c|}
\hline & Sectors & Number of enterprises & Frequency \\
\hline \multirow{7}{*}{ Industries } & Gastronomy & 66 & $14.77 \%$ \\
\hline & Furniture & 53 & $11.86 \%$ \\
\hline & Clothing manufacturing & 68 & $15.21 \%$ \\
\hline & Fashion retailing & 63 & $14.09 \%$ \\
\hline & Hotel and tourism & 64 & $14.32 \%$ \\
\hline & Building material & 62 & $13.87 \%$ \\
\hline & Bakery & 71 & $15.88 \%$ \\
\hline \multirow{5}{*}{$\begin{array}{c}\text { Age } \\
\text { (in years) }\end{array}$} & $0-5$ & 55 & $12.30 \%$ \\
\hline & $+5-10$ & 158 & $35.35 \%$ \\
\hline & $+10-20$ & 140 & $31.32 \%$ \\
\hline & $+20-30$ & 60 & $13.42 \%$ \\
\hline & +30 & 34 & $7.61 \%$ \\
\hline \multirow{5}{*}{$\begin{array}{c}\text { Size } \\
\text { (number of employees) }\end{array}$} & $1-5$ & 177 & $39.60 \%$ \\
\hline & $5-10$ & 118 & $26.40 \%$ \\
\hline & $10-20$ & 87 & $19.46 \%$ \\
\hline & $20-30$ & 29 & $6.49 \%$ \\
\hline & +30 & 36 & $8.05 \%$ \\
\hline \multirow{3}{*}{ Region } & Metropolitan region & 329 & $73.60 \%$ \\
\hline & Others & 118 & $26.40 \%$ \\
\hline & Total of enterprises & 447 & \\
\hline
\end{tabular}

Despite the differences, Tables 4 and 5 indicate that firms use to rely on business-society and supplier relationships, but they have restrictions on the results obtained. The high standard deviation and variance suggests heterogeneity among the firms, and the minimum equal to zero indicates the existence of firms where the resources are incipient. According to Sebrae (Sebrae, 2018), Brazilian
MSEs have some difficult to develop their management, mainly concerning financial resources, demanding support policies.

Table 6 presents the correlation analysis. There are moderate and significant positive correlations between the variables, as expected, since the development of a managerial resource can foster another (Jong \& Vermeulen, 2006).

Table 4. Resources by industry sector.

\begin{tabular}{|c|c|c|c|c|c|c|c|}
\hline Industries & Leadership & Information & People & Society & Supplier & Customer & Results \\
\hline Gastronomy & 0.335 & 0.279 & 0.259 & 0.461 & 0.414 & 0.332 & 0.012 \\
\hline Furniture & 0.454 & 0.379 & 0.397 & 0.457 & 0.548 & 0.590 & 0.256 \\
\hline $\begin{array}{l}\text { Clothing } \\
\text { manufacturing }\end{array}$ & 0.427 & 0.325 & 0.414 & 0.439 & 0.475 & 0.441 & 0.211 \\
\hline Fashion retailing & 0.519 & 0.457 & 0.396 & 0.629 & 0.518 & 0.499 & 0.137 \\
\hline Hotel and tourism & 0.423 & 0.422 & 0.412 & 0.472 & 0.490 & 0.515 & 0.113 \\
\hline Building material & 0.171 & 0.191 & 0.190 & 0.278 & 0.261 & 0.136 & 0.007 \\
\hline Bakery & 0.365 & 0.232 & 0.331 & 0.483 & 0.397 & 0.255 & 0.059 \\
\hline Kruskal-Wallis test & $105.38^{* * *}$ & $90.99^{* * *}$ & $82.63^{* * *}$ & $91.63^{* * *}$ & $82.12^{* * *}$ & $185.95^{* * *}$ & $180.80^{* * *}$ \\
\hline
\end{tabular}

Note. ${ }^{* * *} p<0,01$. 
Table 5. Descriptive statistics.

\begin{tabular}{|c|c|c|c|c|c|c|c|}
\hline Variables & Mean & $\begin{array}{l}\text { Standard } \\
\text { deviation }\end{array}$ & Minimum & Maximum & Variance & Asymmetry & Kurtosis \\
\hline Leadership & 0.383 & 0.218 & 0 & 1 & 0.047 & 0.557 & -0.088 \\
\hline Information & 0.324 & 0.204 & 0 & 1 & 0.042 & 0.545 & 0.225 \\
\hline People & 0.342 & 0.205 & 0 & 1 & 0.042 & 0.754 & 0.335 \\
\hline Society & 0.461 & 0.214 & 0 & 1 & 0.046 & 0.113 & -0.192 \\
\hline Supplier & 0.441 & 0.201 & 0 & 1 & 0.041 & 0.171 & -0.169 \\
\hline Customer & 0.390 & 0.234 & 0 & 1 & 0.055 & 0.452 & -0.246 \\
\hline Results & 0.110 & 0.155 & 0 & 1 & 0.024 & 2.038 & 6.120 \\
\hline
\end{tabular}

Table 6. Correlation variables analysis.

\begin{tabular}{|c|c|c|c|c|c|c|c|}
\hline Variables & Leadership & Information & People & Society & Supplier & Customer & Results \\
\hline Leadership & 1 & & & & & & \\
\hline Information & 0.7236 & 1 & & & & & \\
\hline People & 0.7032 & 0.6142 & 1 & & & & \\
\hline Society & 0.5676 & 0.4950 & 0.5156 & 1 & & & \\
\hline Supplier & 0.6875 & 0.6575 & 0.6343 & 0.4642 & 1 & & \\
\hline Customer & 0.6747 & 0.6733 & 0.5667 & 0.4151 & 0.6367 & 1 & \\
\hline Results & 0.4560 & 0.4314 & 0.4210 & 0.2636 & 0.4680 & 0.5466 & 1 \\
\hline
\end{tabular}

\section{Confirmatory factor analysis results}

Initially, the CFA was performed according to the model presented in Figure 2. Nevertheless, the factor loading and adjustments indices analysis suggested improvements in the original model and identified a relationship between management capability and supplier relationship.

The adjustment indices of the respecified model do not differ from the recommended values, as presented in Table 7 . The $\chi 2$ equal 26,66 and $p=0,014$ indicate adequate reproduction of the covariance sample. The robust RMSEA equal 0.053 suggests that the model exactly reproduces the covariance matrix, and the SRMR equal 0.024 demonstrate a good fit of the model.

The robust CFI $=0.991$ and robust $\mathrm{TLI}=0.985$ also denote a good fit. Lastly, observed reliability and validity tests were performed. The Cronbach's alpha $(\alpha=0.897)$ and McDonald's omega $(\omega t=0.912)$ demonstrate that the model has satisfactory reliability, the AVE $=0.626$ indicates the convergent validity, and the HMTM $=0.87$ indicates the divergent validity, as suggested by Gana and Broc (2019). Table 7 presents the model adjustment indices of the model relating them to the recommended values.

Table 7. Model adjustment indices.

\begin{tabular}{lccc}
\hline \multicolumn{1}{c}{ Model adjustment indices } & Results & Recommended value & Reference \\
\hline$\chi^{2}$ & $26.66, p=0.014$ & $p<0.05$ & Brown $(2015)$ \\
Robust RMSEA & 0.053 & $\leq 0.08$ & Brown $(2015)$ \\
SMR & 0.024 & $\leq 0.05$ & Brown $(2015)$ \\
Robust CFI & 0.991 & $>0.95$ & Brown $(2015)$ \\
Robust TLI & 0.985 & $>0.95$ & Brown (2015) \\
Cronbach's alpha $(\alpha)$ & 0.897 & $>0.70$ & Gana and Broc (2019) \\
McDonald's omega $\left(\omega_{\mathrm{t}}\right)$ & 0.912 & $>0.70$ & Gana and Broc (2019) \\
AVE & 0.626 & $>0.5$ & Gana and Broc (2019) \\
HTMT & 0.870 & $<0.90$ & Gana and Broc (2019) \\
\hline
\end{tabular}

Note. The table presents the fit, reliability, and validity indices to evaluate the model, their recommended values, and references. 
Figure 3 presents the model diagram with the CFA results, where it is possible to observe the relations between the resources and the capabilities, detailed in Table 8.

Figure 3 and Table 8 present the established relations between resources and management and transaction capabilities. The results indicate that the resources are significant to represent business-driven capabilities.

The coefficients presented in the CFA suggest that management capability is composed by the leadership role in the formulation and conduction of the firm's strategies (coefficient $=0.883$ ), sharing information and knowledge with stakeholders (coefficient $=0.823$ ), business-society relationship (coefficient $=0.611$ ), and people management (coefficient $=0.780$ ), which confirms the hypothesis. However, the results also indicate that supplier relationship contributes to the company's ability to manage its assets, presenting a positive and moderate relation to management capability (coefficient $=0.797$ )

Zawislak et al. (2018) suggest that management capability is related to three central elements: strategic planning, human resources, and norms and procedures. The results obtained corroborate the authors but indicate the relevance of other resources in the MSEs context.

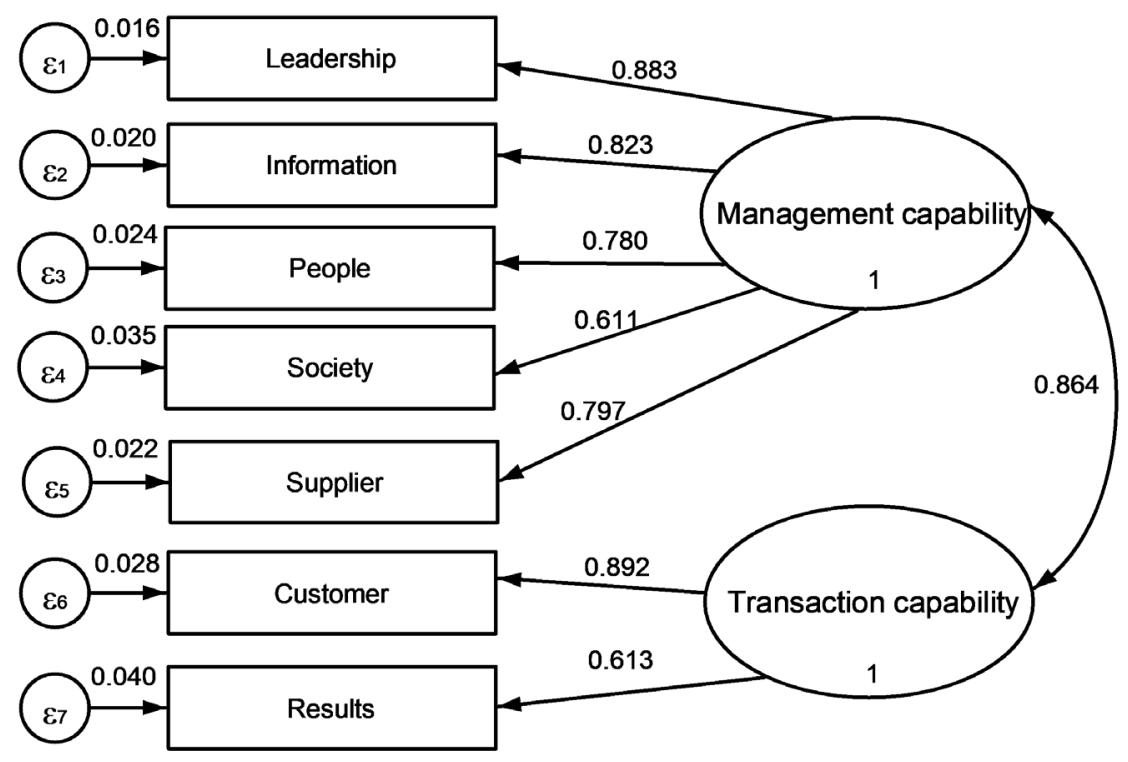

Figure 3. Standardized model coefficients.

The ellipses represent the latent variables, and the rectangles represent the observed variables, measured through the aspects presented in Table 2.

Table 8. Result of hypothesis tests.

\begin{tabular}{|c|c|c|c|c|}
\hline Hypothesis & Relationship & Coefficient & Standard error & Results \\
\hline $\mathrm{H}_{1}$ & Leadership $\leftarrow$ Management Capability & $0.883^{* * *}$ & 0.016 & Confirmed \\
\hline $\mathrm{H}_{2}$ & Information $\leftarrow$ Management Capability & $0.823^{* * *}$ & 0.020 & Confirmed \\
\hline $\mathrm{H}_{3}$ & People $\leftarrow$ Management Capability & $0.780^{* * *}$ & 0.024 & Confirmed \\
\hline $\mathrm{H}_{4}$ & Society $\leftarrow$ Management Capability & $0.611^{* * *}$ & 0.035 & Confirmed \\
\hline- & Supplier $\leftarrow$ Management Capability & $0.797^{* * *}$ & 0.022 & - \\
\hline $\mathrm{H}_{6}$ & Customer $\leftarrow$ Transaction Capability & $0.892^{* * *}$ & 0.028 & Confirmed \\
\hline $\mathrm{H}_{7}$ & Results $\leftarrow$ Transaction Capability & $0.613^{* * *}$ & 0.040 & Confirmed \\
\hline $\mathrm{H}_{8}$ & Transaction CapabilityヶManagement Capability & $0.864^{* * *}$ & 0.033 & Confirmed \\
\hline
\end{tabular}

Note. The model adjustment indices and their respective recommended values are presented in Table $7 .{ }^{* * *} p<0,01$. 
In general, the results confirm the literature perspective. Some authors have been discussing the relevance of the leadership to innovation development (Bayarçelik et al., 2014; Kim et al., 2018; Le \& Lei, 2019; Martínez-Román \& Romero, 2017; Vasconcelos \& Oliveira, 2018). This study verifies a positive relationship between leadership and management capability, accepting $\mathrm{H}_{1}$. The result highlights that the leader contributes to the capacity to coordinate business activities, promoting innovations. The leader's ability to develop strategies, to apply and share knowledge, and to encourage employee participation promote the development and coordination of new ideas.

The research also demonstrates that management capability is related to information and knowledge sharing. The significant relationship between the variables enables the acceptance of $\mathrm{H}_{2}$. Kim et al. (2018), Le and Lei (2019), Martínez-Román and Romero (2017) and Vasconcelos and Oliveira (2018) have already demonstrated that networking promotes innovation and facilitates the access to new knowledge. The results corroborate the authors and indicate that the networks contribute to management capability, which explains its relationship with innovation.

The results suggest that networking allows the MSEs to obtain information that promotes new abilities and activities. The benchmarking with competitors facilitates the identification of improvement opportunities. The register and sharing of learned lessons with the team can assist the execution of processes and new routines. Therefore, it appears that information sharing facilitates the knowledge and skill managements, enabling the firms to achieve their objectives more efficiently.

Likewise, the CFA analysis demonstrates that people management contributes to management capability, allowing acceptance of $\mathrm{H}_{3}$. As Penrose (1959) suggests, the firm is a bundle of resources, and human resources, as the tangible ones, are relevant to the firm growth. The results of the study indicate that the definitions of roles and tasks, employee training, and well-being programs incentivize employee development and autonomy to promote new ideas, modify tasks and routines, and develop innovations.

The management capability is also composed of the business-society relationship, allowing acceptance of $\mathrm{H}_{4}$. The result suggests that meeting legal and social requirements facilitates the activities coordination and favors innovation. The legal, social, and environmental requirements demand coordination of efforts that drive firms to redesign their activities and processes, as suggested by Vasconcelos and Oliveira (2018).
In contrast, the supplier relationship is not associated with transaction capability, rejecting $\mathrm{H}_{5}$. For Zawislak et al. (2018), the careful selections of the suppliers and the imposition of trading conditions are crucial elements to the transaction capability. However, the absence of the expected relationship can be explained by the weak bargaining power that small firms exert over their suppliers, restricting competitive advantage.

Oppositely, it is possible to observe a significant relation with the management capability, which emphasizes the relevance of the partnership with suppliers to improve the production process, as Iddris (2019) and Kamasak (2015) propose. Furthermore, the supplier's evaluation and recruitment, and the process mapping and control, can favor the reformulation of tasks and routines and facilitate innovation development.

The transaction capability, that is, the capacity to reduce the transaction costs, is composed of the customer relationship (coefficient $=0.892$ ) and the results obtained by the firm (coefficient $=0.613$ ). Several authors discuss the importance of customer relationship to the promotion of innovation (Bayarçelik et al., 2014; Genis-Gruber \& Ögüt, 2014; Iddris, 2019; Kamasak, 2015; Silva et al., 2012; Vasconcelos \& Oliveira, 2018). They suggest that proximity with clients favors the companies to understand their necessities and develop new products and services.

This study observes that the customer relationship supports the transaction capability, once the results verify a positive and significant relation between the resource and capability, allowing acceptance of $\mathrm{H}_{6}$. The lack of knowledge about consumption habits is a decisive factor for the mortality of companies (Sebrae, 2018). Oppositely, the efforts to analyze the customers' expectations and evaluate their complaints and satisfaction improve the innovation development process, as suggested by Bayarçelik et al. (2014), Kamasak (2015), Iddris (2019) and Vasconcelos andOliveira (2018). But it also facilitates customer loyalty and retention, which stimulates the reduction of transaction costs, according to Zawislak et al. (2018).

The CFA indicates that the results obtained by the MSEs contribute to transaction capability, allowing acceptance of $\mathrm{H}_{7}$. Although the firms have financial restrictions, as presented in Table 4, their performance seems to be relevant to firms commercialize their products. This preposition corroborates Bayarçelik et al. (2014) and Vasconcelos et al. (2020), which emphasize the relevance of financial and non-financial results in the development of the innovation. 
It is also observed a positive and significant relationship between management and transaction capability, confirming $\mathrm{H}_{8}$. As Zawislak et al. (2012) propose, the business-driven capabilities are related and jointly support innovation. Despite the moderate correlation, the HTMT test pointed divergent validity of constructs, reinforcing its distinction.

Lastly, the robustness of the model was analyzed through its replication in other samples, which can use out-of-the-sample or in-sample validation. In the outof-the-sample, the results are comparable to external data, and therefore, it is considered more accurate (Inoue \& Kilian, 2005). However, the method faces some difficulties, as it may require ample samples do deal with the dimensionality of relationships.

In this study, the restrictions on access to the database made it unviable to get an additional sample with a reasonable size to validate the model. For that reason, in-sample validation was used, replicating the model in five random sub-samples with 300 firms, obtained from the initial sample.

For Inoue and Kilian (2005), the use of the in-sample method does not reduce the reliability of the results. Otherwise, it favors the development of theoretical insights about the model. Furthermore, complementary tests were performed, such as Cronbach's alpha, McDonald's omega, AVE, and HTMT, attesting the reliability and the convergent and divergent validities of the model and sub-samples.

The results of the robustness analysis demonstrate that the coefficients of the relationships remained significantly, and fit the confidence interval of the original model. As can be seen, the $\chi 2$ of the samples 4 and 5 were not statistically significant, but this result is sensible to the sample size and non-normality data (Tanaka, 1993). For that reason, it is necessary to observe the adjustment indices, which indicated the model's robustness and reliability.

Table 9. Comparison of samples results.

\begin{tabular}{|c|c|c|c|c|c|}
\hline Relation & Sample 1 & Sample 2 & Sample 3 & Sample 4 & Sample 5 \\
\hline Leadership $\leftarrow$ Management Capability & $0.881^{* * *}$ & $0.897^{* * *}$ & $0.872^{* * *}$ & $0.886^{* * *}$ & $0.867^{* * *}$ \\
\hline Information $\longleftarrow$ Management Capability & $0.826^{* * *}$ & $0.843^{* * *}$ & $0.828^{* * *}$ & $0.829^{* * *}$ & $0.836^{* * *}$ \\
\hline People $\leftarrow$ Management Capability & $0.762^{* * *}$ & $0.783^{* * *}$ & $0.783^{* * *}$ & $0.811^{* * *}$ & $0.790^{* * *}$ \\
\hline SocietyヶManagement Capability & $0.607^{* * *}$ & $0.609^{* * *}$ & $0.623^{* * *}$ & $0.662^{* * *}$ & $0.603^{* * *}$ \\
\hline Supplier $\leftarrow$ Management Capability & $0.770^{* * *}$ & $0.806^{* * *}$ & $0.825^{* * *}$ & $0.810^{* * *}$ & $0.784^{* * *}$ \\
\hline Customer $\leftarrow$ Transaction Capability & $0.899^{* * *}$ & $0.900^{* * *}$ & $0.884^{* * *}$ & $0.911^{* * *}$ & $0.904^{* * *}$ \\
\hline Results $\leftarrow$ Transaction Capability & $0.631^{* * *}$ & $0.643^{* * *}$ & $0.617^{* * *}$ & $0.624^{* * *}$ & $0.638^{* * *}$ \\
\hline Transaction Capability $\leftarrow$ Management Capability & $0.829^{* * *}$ & $0.866^{* * *}$ & $0.873^{* * *}$ & $0.873^{* * *}$ & $0.871^{* * *}$ \\
\hline$\chi^{2}$ & $31.467^{* * *}$ & $31.832^{* * *}$ & $32.680^{* * *}$ & 13.337 & 17.219 \\
\hline Robust CFI & 0.981 & 0.983 & 0.981 & 0.996 & 0.996 \\
\hline Robust TLI & 0.969 & 0.972 & 0.970 & 0.993 & 0.993 \\
\hline Robust RMSEA & 0.074 & 0.075 & 0.076 & 0.037 & 0.036 \\
\hline SMR & 0.033 & 0.026 & 0.031 & 0.024 & 0.021 \\
\hline Cronbach's alpha & 0.891 & 0.904 & 0.901 & 0.909 & 0.899 \\
\hline McDonald's omega & 0.913 & 0.923 & 0.920 & 0.928 & 0.916 \\
\hline AVE & 0.622 & 0.646 & 0.630 & 0.661 & 0.630 \\
\hline HTMT & 0.834 & 0.870 & 0.871 & 0.871 & 0.884 \\
\hline
\end{tabular}

Note. Each sample is composed by 300 firms selected randomly from the initial sample used in this research to analyze the model robustness. The model adjustment indices can be evaluated using the recommended values presented in Table $7 .{ }^{* * *} p<0,01$.

Lastly, the estimations of latent variables were performed, and Figure 4 presents the scatter plot. The result demonstrates a linear relation between the business-driven capabilities, corroborating the CFA results.
In Figure 4, it is possible to notice a concentration of MSEs in the center for the lowest left quadrant, which reveals constraints faced by the firms. The figure also presents differences among the industries analyzed. The building 
material and bakery industries, for example, are concentrated in the quadrant of lowest transaction and management capability, suggesting that these firms may face harder obstacles in developing innovations. The furniture and fashion retailing industries are concentrated in the quadrant of the highest transaction and management capability, indicating the facilities of these segments to develop resources and abilities to innovate.
The Kruskal-Wallis test confirms these results and indicates differences among the industries. Table 10 shows that the building materials industry presents the lowest performance among the industries analyzed for both capabilities, while the furniture and fashion retailing industries have the best results. Although the gastronomy and bakery industries register low capabilities performances, Figure 4 demonstrates that there is a large dispersion of firms, indicating that some MSEs can overcome the obstacles and develop managerial resources.

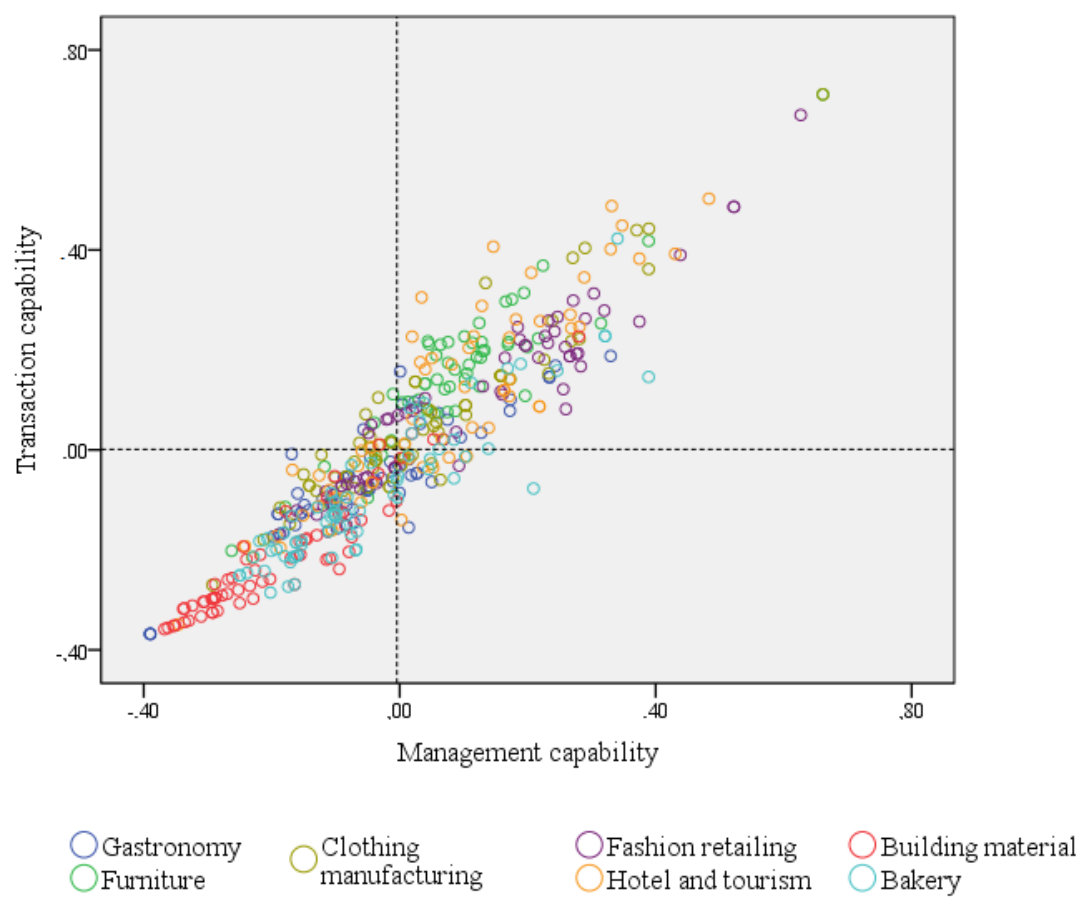

Figure 4. Scatter diagram of the innovation capabilities.

The scatter diagram presents the value related to the estimates of the latent variables of the firms. The $\mathrm{x}$-axis indicates the management capability, and the $\mathrm{y}$-axis indicates the transaction capabilities, identified by the industries. The building material and bakery industries present a concentration of firms with the lowest transaction and management capabilities, whiles the furniture industry is concentrated on the highest capabilities.

Table 10. Transaction and management capabilities by industries.

\begin{tabular}{lcr}
\hline Industry & Transaction capability & Management capability \\
\hline Gastronomy & -0.064 & -0.051 \\
Furniture & 0.154 & 0.088 \\
Clothing manufacturing & 0.057 & 0.039 \\
Fashion retailing & 0.105 & 0.114 \\
Hotel and tourism & 0.087 & 0.066 \\
Building material & -0.217 & -0.191 \\
Bakery & -0.092 & -0.049 \\
Kruskal-Wallis test & $187.91^{* * *}$ & $134.41^{* * *}$ \\
\hline
\end{tabular}

Note. ${ }^{* * *} p<0,01$. 
In general, the results indicate heterogeneity in innovation capabilities in MSEs, contrasting to Zawislak et al. (2018), which can be explained by the barriers and obstacles that each industry faces. Despite these counterpoints, the MSEs structure different arrangements to develop their abilities and promote innovations, which require efforts and support to their needs.

\section{CONCLUSION}

For Teece et al. (1997), the excess of strategy formulation can lead to disinvestments in dynamic capabilities. Nevertheless, this study suggests that investments in dynamic capability and managerial resources can result in efficient innovation strategies. However, identifying and measuring dynamic capabilities is still a requirement. For that reason, this research is an effort to demonstrate how innovation capability can be understood in MSEs, given the obstacles they face to access and use technologies.

Although the technology is relevant to innovate (Dosi et al., 1988), the study demonstrates that managerial abilities are not only supplemental resources, as suggested by Guan and Ma (2003). Contrarily, they became central assets to develop innovations in low-technological intensity firms. Besides demonstrating the relevance of management and transaction capabilities, the study indicates how these capabilities are raised and operationalized, which may be a relevant contribution to the literature since there is no consensus on the theme (Iddris, 2019).

Previous studies have already analyzed the resources as drivers of innovation capability. However, they focus on a direct and individualized relationship. Kim et al. (2018), Le and Lei (2019) and Martínez-Román and Romero (2017), for example, highlight the relevance of leadership and network to innovations development, Iddris (2019) and Kamasak (2015) point the relationship with supplier and consumers, and Vasconcelos et al. (2020) emphasize the financial performance.

Nevertheless, this study covers a broader perspective and contemplates the interactions among the resources presented in the literature. The results corroborate the previous studies and demonstrate the relevance of the resources to the innovations in MSEs. However, it states an indirect relationship between resources and innovation and reveals the resource contributions to the management and transaction capabilities.

The results demonstrate that management capability is composed of business-society relationship, supplier relationship, leadership, information and knowledge sharing, and people management. And the transaction capability is composed of customer relationship and results obtained by the firm.

Based on resource-based view theory, the study proposes a framework that expands the model presented by Zawislak et al. (2018) and evidences new resources (leadership, information and knowledge, results) and settings to the innovation capabilities. Contrary to authors, the research verifies that supplier relationship is not related to transaction capability, which can be explained by the weak bargaining power of small firms that difficult the price, delivery, and terms and conditions negotiations. However, a strong relationship with management capability is identified. Although the firms do not obtain commercial advantages, the supplier relationship improves internal processes and activities, as Kamasak (2015) observes.

The differences between the resources settings and capabilities reinforce the need for a specific analysis in MSEs. Differently to Zawislak et al. (2018), the study observes that the capabilities are not homogeneous, and the firms can develop and combine the resources according to environmental demands and restrictions, as proposed by Penrose (1959). To overcome these barriers, it is necessary to develop programs and policies that provide instructions, advisory, and consultancy to support MSEs to overcome the restrictions in resource use.

The article presents a small contribution to the dynamic capabilities theory and proposes a limited perspective of the Zawislak et al. (2012) model, focusing on business-driven capabilities. However, the research is an effort to identify resources related to innovation capabilities in MSEs, supporting small firms to develop their resources and obtain extraordinary profits from innovation activities (Schumpeter, 1988). However, there is no attempt to limit or exhaust the contribution of resources, but rather demonstrate its relevance to innovation development.

The model presented demonstrates good specification and robustness, evidenced by reliability and validity indices and robustness tests. However, limitations on access to data made it unviable the replication of the model in outof-the-sample. Furthermore, the data reveal the manager's perception, and not necessarily the firm reality, and the innovation capabilities are reconfigured by managerial decisions, as Tometich, Fracasso, Zen and Engelman (2019) propose. For that reason, this paper suggests the development of new studies using longitudinal data and technology-driven capability. In addition, the application in other industries, using different technology intensity, can reveal new configurations. 


\section{REFERENCES}

Alves, A., Barbieux, D., Reichert, F., Tello-Gamarra, J. \& Zawislak, P. (2017). Innovation and dynamic capabilities of the firm: Defining an assessment model. Revista de Administração de Empresas, 57(3), 232-244. https://doi.org/10.1590/s0034-759020170304

Bayarçelik, E., Taşel, F., \& Apak, S. (2014). A research on determining innovation factors for SMEs. Procedia - Social and Behavioral Sciences, 150, 202-211. https://doi.org/10.1016/j.sbspro.2014.09.032

Brown, T. (2015). Confirmatory factor analysis for applied research. New York, NY: The Guilford Press.

Bos-Brouwers, H. (2009). Corporate sustainability and innovation in SMEs: Evidence of themes and activities in practice. Business Strategy and the Environment, 19(7), 417-435. https://doi.org/10.1002/bse.652

Coase, R. H. (1937). The nature of the firm. Economica, 4(16), 386-405. Retrieved from https://www.jstor.org/stable/2626876?seq=1

Dosi, G., Freeman, C., \& Nelson, R. (1988). Technical change and economic theory (Vol. 988). London: Printer.

Eisenhardt, K. M., \& Martin, J. A. (2000). Dynamic capabilities: what are they? Strategic Management Journal, 21(10-11), 1105-1121. https://doi. org/10.1002/1097-0266(200010/11)21:10/11<1105::AID$\underline{\mathrm{SMJ} 133>3.0 . \mathrm{CO} ; 2-\mathrm{E}}$

El Elj, M., \& Abassi, B. (2014). The determinants of innovation: an empirical analysis in Egypt, Jordan, Syria and Turkey. Canadian Journal of Development Studies, 35(4), 560-578. https://doi.org/10.1080/02255189.2014.934787

Farace, S., \& Mazzotta, F. (2015). The effect of human capital and networks on knowledge and innovation in SMEs. Journal of Innovation Economics, 16(1), 39-71. https://doi.org/10.3917/jie.016.0039

Gana, K., Broc, G. (2019). Structural equation modeling with lavaan. London: John Wiley \& Sons.

Genis-Gruber, A., \& Öğüt, H. (2014). Environmental factors affecting innovation strategies of companies: Customers and suppliers effect. Procedia - Social and Behavioral Sciences, 150(11), 718-725. https://doi.org/10.1016/j.sbspro.2014.09.033

Guan, J., \& Ma, N. (2003). Innovative capability and export performance of Chinese firms. Technovation, 23(9), $737-$ 747. https://doi.org/10.1016/S0166-4972(02)00013-5

Iddris, F. (2019). Innovation capability and product innovation performance: The case of low-tech manufacturing firms. European Business Review, 31(5), 646-668. https://doi.org/10.1016/S0166-4972(02)00013-5

Inoue, A., \& Kilian, L. (2005). In-sample or out-ofsample tests of predictability: Which one should we use? Econometric Reviews, 23(4), 371-402. https://doi.org/10.1081/ETC-200040785
Jong, J., \& Vermeulen, P. (2006). Determinants of product innovation in small firms: A comparison across industries. International Small Business Journal, 24(6), 587-609. https://doi.org/10.1177/0266242606069268

Kamasak, R. (2015). Determinants of innovation performance: A resource-based study. Procedia Social and Behavioral Sciences, 195, 1330-1337. https://doi.org/10.1016/j.sbspro.2015.06.311

Karpak, B., \& Topcu, I. (2010). Small medium manufacturing enterprises in Turkey: An analytic network process framework for prioritizing factors affecting success. International Journal of Production Economics, 125(1), 6070. https://doi.org/10.1016/j.ijpe.2010.01.001

Kim, M., Park, J., \& Paik, J. (2018). Factors influencing innovation capability of small and medium-sized enterprises in Korean manufacturing sector: Facilitators, barriers and moderators. International Journal of Technology Management, 76(3-4), 214-235. https://doi.org/10.1504/IJTM.2018.10012461

Laforet, S., \& Tann, J. (2006). Innovative characteristics of small manufacturing firms. Journal of Small Business and Enterprise Development, 13(3), 363-380. https://doi.org/10.1108/14626000610680253

Laforet, S. (2011). A framework of organizational innovation and outcomes in SMEs. International Journal of Entrepreneurial Behavior of Research, 17(4), 380-408. https://doi.org/10.1108/13552551111139638

Lawson, B., \& Samson, D. (2001). Developing innovation capability in organizations: A dynamic capabilities approach. International Journal of Innovation Management, 5(3), 377-400. https://doi.org/10.1142/S1363919601000427

Le, P., \& Lei, H. (2019). Determinants of innovation capability: The roles of transformational leadership, knowledge sharing and perceived organizational support. Journal of Knowledge Management, 23(3), 527-547. https://doi.org/10.1108/JKM-09-2018-0568

Lee, F., \& Newton, K. (2000). Innovation of SMEs in the knowledge-based economy. Journal of Small Business \& Entrepreneurship, 15(4), 2-31. https://doi.org/10.1080/08276331.2000.10593291

Lei Complementar n. 155, de 27 de outubro de 2016. (2016). Altera a Lei Complementar no 123, de 14 de dezembro de 2006. Retrieved from http://www.planalto.gov.br/ccivil 03/leis/lcp/lcp155.htm

Martínez-Román, J., \& Romero, I. (2017). Determinants of innovativeness in SMEs: Disentangling core innovation and technology adoption capabilities. Review of Managerial Science, 11(3), 543-569. https://doi.org/10.1007/s11846-016-0196-x

Nelson, R. R., \& Winter, S. G. (1982). An evolutionary theory of economic change. Cambridge: Belknap Press. 
Nidumolu, R., Prahalad, C., \& Rangaswami, M. (2009). Why sustainability is now the key driver of innovation. Harvard Business Review, Reprint R0909E. Retrieved from https:// www.academia.edu/8421329/Why Sustainability Is Now the Key Driver of Innovation The Idea in Brief the core idea 1 Article Summary 3 Why Sustainability Is Now the Key Driver of Innovation

Pavitt, K. (1984). Setorial patters of technical change: Towards a taxonomy and a theory. Research Policy, 13(6), p. 343-373. https://doi.org/10.1016/0048-7333(84)90018-0

Penrose, E. (1959). The theory of growth of firm. New York, NY: Oxford University Press.

Popadiuk, S., Luz, A., \& Kretschmer, C. (2018). Dynamic capabilities and ambidexterity: how are these concepts related? RAC. Revista de Administração Contemporânea, 22(5), 639-660. https://doi.org/10.1590/1982-7849rac2018180135

Raghuvanshi, J., Ghosh, P., \& Agrawal, R. (2019). Taxonomy of innovation capability framework with future directions. International Journal of Business Excellence, 17(3), p. $265-$ 289. https://doi.org/10.1504/IJBEX.2019.10019304

Rogers, M. (2004). Networks, firm size and innovation. Small Business Economics, 22(2), 141-153. https://doi.org/10.1023/B:SBEJ.0000014451.99047.69

Saunila, M. (2019). Innovation capability in SMEs: A systematic review of the literature. Journal of Innovation \& Knowledge. https://doi.org/10.1016/j.jik.2019.11.002

Schumpeter, J. A. (1984). Capitalismo, socialismo e democracia. Rio de Janeiro: Zahar.

Schumpeter, J. A. (1988). A teoria do desenvolvimento econômico. São Paulo, SP: Nova Cultural.

Serviço Brasileiro de Apoio às Micro e Pequenas Empresas. (2018). Perfil das microempresas e empresas de pequeno porte 2018. https://www.sebrae.com.br/sites/PortalSebrae/ufs/ro/artigos/ perfil-das-microempresas-e-empresas-de-pequeno-porte2018,a2fb479851b33610VgnVCM1000004c00210aRCR D? origem $=$ tema\&codTema $=2$

Serviço Brasileiro de Apoio às Micro e Pequenas Empresas. (2020). Data SEBRAE. Retrieved from https://datasebrae.com.br/

Silva, M., Mainardes, E., Raposo, M., \& Sousa, G. (2012). Determinantes internos e externos da capacidade inovadora das empresas de serviços portuguesas: Modelo logit. Revista de Gestão, 19(1), 39-54. https://doi.org/10.5700/rege450
Söllner, R. (2010). Human capital diversity and product innovation: a micro-level analysis. Jena Economic Research Papers, 27, 1-33. Retrieved from https://www.econstor.eu/ bitstream/10419/32631/1/625854918.pdf

Tanaka, J. (1993). Multifaced conceptions of fit in strucutural equation models. In K. A. Bollen, \& J. S. Long (Eds.), Testing structural equation models (pp. 10-39). Newbury Park: Sage Publications.

Teece, D. J. (2007). Explicating dynamic capabilities: The nature and microfoundations of (sustainable) enterprise performance. Strategic Management Journal, 28(13), 1319-1350. https://doi.org/10.1002/smj.640

Teece, D. J., Pisano G., \& Shuen A. (1997). Dynamic capabilities and strategic management. Strategic Management Journal, 18(7), 509-533. https://doi.org/10.1002/(SICI)10970266(199708)18:7<509::AID-SMJ882>3.0.CO;2-Z

Tometich, P., Fracasso, E., Zen, A., \& Engelman, R. (2019). A decisão de inovar e o movimento das capacidades dinâmicas. Gestâo \& Produção, 26(2), e3627. http://dx.doi.org/10.1590/0104-530x-3627-19

Vasconcelos, R. B. B., \& Oliveira, M. R. G. (2018). Determinantes da inovação em micro e pequenas empresas: Uma abordagem gerencial. Revista de Administração de Empresas, 58(4), 249364. http://dx.doi.org/10.1590/s0034-759020180402

Vasconcelos, R. B. B, Vieira, R. S., \& Silveira, D. S. (2020). What's the recipe to innovate? An analysis of the determinants of the degree of innovation in the gastronomy segment. International Journal of Innovation Management, 24(1), 2050005. https://doi.org/10.1142/S136391962050005X

Williamson, O. (1985). The economic institutions of capitalism. New York, NY: Free Press.

Zawislak, P., Alves, C., Tello-Gamarra, J., Barbieux, D., \& Reichert, F. (2012). Innovation capability: from technology development to transaction capability. Journal of Technology Management \& Innovation, 7(2), 14-27. https://doi.org/10.4067/S0718-27242012000200002

Zawislak, P., Fracasso, E., \& Tello-Gamarra, J. (2018). Technological intensity and innovation capability in industrial firms. Innovation \& Management Review, 15(2), 189-207. https://doi.org/10.1108/INMR-04-2018-012 


\section{Authorship}

\section{Renata Braga Berenguer de Vasconcelos*}

Universidade Federal de Pernambuco, Centro de Ciências Sociais Aplicadas

Av. Prof. Moraes Rego, no 1235, Cidade Universitária, 50670-901, Recife, PE, Brazil.

E-mail address: renata_berenguer@hotmail.com

(1) https://orcid.org/0000-0003-4184-5694

\section{Joséte Florencio dos Santos}

Universidade Federal de Pernambuco, Centro de Ciências Sociais Aplicadas

Av. Prof. Moraes Rego, no 1235, Cidade Universitária, 50670-901, Recife, PE, Brazil.

E-mail address: jfs@ufpe.br

(1) https://orcid.org/0000-0002-5366-2548

\section{Jackeline Amantino de Andrade}

Universidade Federal de Pernambuco, Centro de Ciências Sociais Aplicadas

Av. Prof. Moraes Rego, no 1235, Cidade Universitária, 50670-901, Recife, PE, Brazil.

E-mail address: jackeline.amantino@gmail.com

(1) https://orcid.org/0000-0002-6451-4049

* Corresponding Author

\section{Funding}

The authors thank the Fundaçáo de Amparo à Ciência e Tecnologia of Pernambuco for the financial support.

\section{Conflict of Interests}

The authors have stated that there is no conflict of interest.

\section{Copyrights}

RAC owns the copyright to this content.

\section{Authors' Contributions}

$1^{\text {st }}$ author: conceptualization (equal); data curation (leader); formal analysis (leader); investigation (leader); methodology (leader); visualization (equal); validation (leader); writing original draft (equal); writing - review and editing (equal).

$2^{\text {nd }}$ author: conceptualization (equal); validation (supporting); project administration (leader); writing original draft (equal); writing - review and editing (equal); methodology (supporting); visualization (equal); funding acquisition (leader).

$3^{\text {rd }}$ author: conceptualization (equal); (supporting) investigation (supporting); project administration (supporting); supervision (leader); writing - original draft (equal); writing - review and editing (equal); visualization (equal).

\section{Plagiarism Check}

The RAC maintains the practice of submitting all documents approved for publication to the plagiarism check, using specific tools, e.g.: iThenticate.

\section{Peer Review Method}

This content was evaluated using the double-blind peer review process. The disclosure of the reviewers' information on the first page, as well as the Peer Review Report, is made only after concluding the evaluation process, and with the voluntary consent of the respective reviewers and authors.

\section{Data Availability}

All data and materials were made publicly available through the Harvard Dataverse platform and can be accessed at:

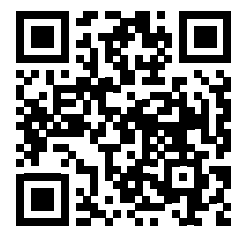

Renata Braga Berenguer de Vasconcelos; Joséte Florencio dos Santos; Jackeline Amantino de Andrade, 2020, "Replication Data for: Innovation in micro and small enterprises: Resources and capabilities", https://doi.org/10.7910/DVN/TODLHW, Harvard Dataverse, V1. 